\title{
Coal Analysis in Thermal Power Plant
}

\author{
Ramandeep Kaur $^{1}$, Ishwinder Singh ${ }^{2}$, Dr. Jyoti Saxena ${ }^{3}$, Sonia Grover ${ }^{4}$ \\ PG Student (Power Engineering.), Dept. of EE, GZS Campus CET, Bathinda, India ${ }^{1,2}$ \\ Professor and Head of Electrical Engineering Department, GZS Campus CET, Bathinda, India ${ }^{3}$
}

Assistant Professor at GZS Campus CET, Bathinda, India ${ }^{4}$

\begin{abstract}
Energy is an important factor today in determining the economy of a country. Present emphasis is to elicit maximum energy out of the resources so as to reduce the running cost of a plant or an organisation. Coal is one of the most economical fuel as compared to other fuels such as gas or oil. Quality of coal is thus of primary importance in improving the efficiency of the Power Plant. This paper presents coal analysis at Thermal Power Plant situated in Punjab to determine the characteristics thus, the rank of coal. The possible recommendations are also given to improve the performance of coal so that the efficiency of the plant can be improved.
\end{abstract}

Keywords: Thermal Power Plant, Proximate Analysis, Coal, Efficiency.

\section{INTRODUCTION}

In India About $70 \%$ of the electrical energy is generated analysis is to determine the rank of the coal along with its from fossil fuels. Coal consumption is about $40 \%$ of Intrinsic characteristics. Various components of coal India's total energy consumed. The highest rate of annual finally the carbon composition of coal is found. growth $(11.66 \%)$ from 2012-13 to 2013-14 in installed capacity was for Thermal Plant. So, the major amount of electricity produced in India depends on Thermal Power Plants. So, the quality of coal is major consideration for the performance of Thermal Plant. Poor quality coal may not only result in poor efficiency but can also effect the life of Power Plant. Major parameters for the analysis of coal are moisture, volatile matter, ash and fixed carbon.

Thermal power plants have a low efficiency due to the involvement of heat exchanges. So, each energy saving step is of considerable importance towards the efficiency of Thermal Plant. Energy audit plays an important role in identifying the energy inefficient areas. Possible measures can be undertaken to recover the losses in such areas.

In this paper proximate coal analysis is performed on coal. It is used to study the rank or quality of coal. Poor quality of coal may damage the blades of turbine and also results in reduced efficiency of the Power Plant. The analysis is carried out at Guru Hargobind Thermal Plant situated at Lehra Mohabbat, Punjab. Jharkhand is the major source of coal for the plant.

\section{TYPES OF COAL ANALYSIS}

Analysis of coal is very important part during boiler efficiency test. This analysis helps find out the quality of coal. Quality of coal is calculated by the percentages of different constituents which help in categorizing it as a high grade or lower grade coal.

There are two types of tests involved in the analysis of coal:

\section{A. Proximate Analysis of coal}

\section{B. Ultimate analysis of coal}

Ultimate analysis of coal is done on annual basis. It is used to find the chemical composition of coal that is Nitrogen, Sulphur, Oxygen, Hydrogen and Carbon etc. It is essential in calculating heat balance in any process.

\section{III.COAL ANALYSIS}

Main components of coal identified in approximate analysis are:

\section{A. Moisture}

Moisture is a main property of coal. All types of coal are mined wet. Groundwater and other extraneous moisture are known as adventitious moisture. Moisture take place in four possible forms within coal that are:

1) Surface moisture: Water held on the surface of coal particles.

2) Hydroscopic moisture: Water held by capillary action within the micro fractures of the coal.

3) Decomposition moisture: Water held within the coal's decomposed organic compounds.

4) Mineral moisture: Water comprises part of the crystal structure of hydrous silicates such as clays.

B. Ash

The non-combustible matter that remains after the coal is burnt is the ash. During combustion, it represents the bulk mineral matter after carbon, oxygen, sulfur and water (including from clay) have been driven off.

\section{Fixed Carbon}

It includes the determination of carbon, moisture, ash, It is the carbon found in material after moisture, ash and volatile matter and fixed carbon. This gives quick and valuable information.

Proximate analysis of coal is done in thermal power plant on regular interval. The main purpose of coal sample

volatile matter are driven off. The sum of percentages of ash, moisture and volatile matter subtracted from 100 gives the fixed carbon. This is the procedure followed in proximate analyses. 
Volatile matter is calculated from the ultimate analyses performed at the Power Plant.

\section{IV.CALCULATIONS}

MOISTURE:

Weight of empty crucible

Weight of crucible +sample

$\mathrm{W} 1=63.0105 \mathrm{~g}$

Weight of crucible +sample after heating W3 $=72.7608 \mathrm{~g}$

$\%$ Moisture

[(W2-W3) / (W2-W1)] X 100 $=2.63 \%$

Ash:

Weight of the empty crucible

Weight of crucible + sample

Weight of crucial + ash

$\%$ Ash

$\mathrm{W} 4=18.1391 \mathrm{~g}$

$\mathrm{W} 5=19.2644 \mathrm{~g}$

$\mathrm{W} 6=18.6895 \mathrm{~g}$

[(W6-W4) / (W5-W4)] x 100 $=48.91 \%$

Fixed Carbon:

$\%$ Fixed Carbon $=100-[\%$ Moisture $+\%$ Ash $+\%$ VM $]$ $=100-[2.63+48.91+14.98]=33.48 \%$

\section{CONCLUSION}

In the table given below the performance and present coal is compared. Based on the deviation or proportion of components of coal found in the above sections conclusions can be drawn.

TABLE I: COAL ANALYSIS PERFORMED AT THERMAL POWER PLANT

\begin{tabular}{|l|l|l|l|}
\hline Sr. No. & Description & $\begin{array}{l}\text { Performance } \\
\text { Coal }(\mathbf{\%})\end{array}$ & $\begin{array}{l}\text { Present Coal } \\
(\boldsymbol{\%})\end{array}$ \\
\hline 1. & Fixed Carbon & 36.37 & 33.48 \\
\hline 2. & $\begin{array}{l}\text { Volatile } \\
\text { Matter }\end{array}$ & 26.1 & 14.98 \\
\hline 3. & Moisture & 7.8 & 2.63 \\
\hline 4. & Ash & 29.4 & 48.91 \\
\hline 5. & GCV & $4530 \mathrm{Kcal} / \mathrm{kg}$ & $3942 \mathrm{Kcal} / \mathrm{kg}$ \\
\hline 6. & Consumption & $115.1 \mathrm{~T} / \mathrm{hr}$. & $130 \mathrm{~T} / \mathrm{hr}$. \\
\hline
\end{tabular}

Fixed Carbon in the coal being used at GHTP is less than the standard performance coal. Ash content is more than recommended which results in lower GCV value of coal.

So the actual consumption of coal is increased by almost $14.9 \mathrm{~T} / \mathrm{hr}$.

- It is recommended that coal of calorific value above $4500 \mathrm{Kcal} / \mathrm{kg}$ is to be used.

- To reduce moisture content, coal should be properly dried by increasing the temperature of primary air .

- It should be properly pulverized.

Study has revealed that if coal is imported Australia or America(these are the major coal exporter) lesser amount of coal feed would be required to generate the same amount of power. Imported coal also have less amount of $\mathrm{CO} 2$ emission. However, imported coal have large amount of $\mathrm{SO} 2$ emission as compared to Indian coal.

\section{ACKNOWLEDGMENT}

The acknowledge support is provided by G.H.T.P. faculty for the collection of data and for plant visit. I would like to express my special thanks of gratitude to my teacher Mahinder Singh (G.Z.S. Campus CET, Bathinda) and my friends and colleagues.

\section{REFERENCES}

1] Y.P. Abbi, Energy Audit: Thermal Power Combined Cycle, and Cogeneration Plants. New Delhi: The Energy and Resources Institute (TERI), 2011.

[2] Albert Thumann, Hand book of energy audits. 7th ed. U.S.A.: The Fairmont Press, Inc., 2007.

[3] A. Chandra and H. Chandra, "Impact of Indian and Imported Coal on Indian Thermal Power Plants", Journal of Scientific and Industrial research, 2004, v. 63, pp 156-162.

[4] Vikas Duhan and Jitender Singh, "Energy Audit of Rajiv Gandhi Thermal Power Plant Hisar", JRPS, International Journal for Research Publication \& Seminar, 2014, v. 5.

[5] PSPCL, "Operation Manual for $2 \times 210$ MW G.H.T.P. Stage-1 Lehra Mohabbat”, Bathinda, Library G.H.T.P., Lehra Mohabbat Tech. Rep., pp 277-01

[6] T.E.R.I., "Energy Audit at Unit -1 of G.H.T.P.”,the energy and Resources institute, New Dehli Tech. Rep. 210-01, 2011.

\section{BIOGRAPHIES}

Ramandeep Kaur has obtained her B.E and is pursuing her PG (Power Engineering) from GZS Campus CET, Bathinda. She has worked as Assistant Professor in the Department of Electrical Engineering in the same institute. Area of her interest are Power Generation and Electrical Machines.

Ishwinder Singh has obtained his B.E and pursuing his PG (Power Engineering) from GZS Campus CET, Bathinda. He has also worked as Assistant Professor in the Department of Electrical Engineering in the same institute. Area of his interest are Electrical Machines.

Dr. Jyoti Saxena is working as Professor and Head of Electrical Engineering Department, GZS Campus CET, Bathinda. Areas of her interest are Communication Systems, Soft Computing, Signal Processing and Communication.

Sonia Grover is working as Assistant Professor at GZS Campus CET, Bathinda. She has completed her post graduation from Guru Nanak Dev Engineering College, Ludhiana.Areas of her interest are Power System. 